УДК: 657

JEL Classification: M 41

\author{
К. В. БЕЗВЕРХИЙ, \\ кандидат економічних наук, \\ докторант кафедри обліку і оподаткування, \\ ДВНЗ “Київський національний економічний університет \\ імені Вадима Гетьмана"; \\ В. П. ПАНТЕЛЕСВ, \\ доктор економічних наук, \\ професор кафедри обліку і оподаткування, \\ Національна академія статистики, обліку та аудиту
}

\title{
Консолідований звіт про управління. Новації управлінської практики звітування
}

Консолідований звіт про управління є новим явищем в практиці звітування в Украӥні, шео обумовлено прийняттям змін до Закону Украӥни "Про бухгалтерський облік та фінансову звітність в Украйні". Консолідований звіт про управління призначений для виведення інформаційного забезпечення групи підприємств на якісно новий рівень. Результати проведеного дослідження забезпечують базу для гармонізаиії звітності в Украйні зі стандартами СС. Вони рекомендуються для застосуванням на всіх групах підприємств України в різних секторах економіки, які повинні будуть складати консолідований звіт про управління.

Ключові слова: консолідована фінансова звітність, консолідований звіт про управління, група підприємств, нефінансова інформація, показник.

Постановка проблеми та їі зв'язок із практичними завданнями. Управління суб'єктами господарювання є доволі складним і трудомістким процесом, що насамперед потребує відповідної інформації, яка б сприяла ефективному прийняттю рішень менеджментом. Так, із прийняттям Закону України «Про внесення змін до Закону України «Про бухгалтерський облік та фінансову звітність в Україні» щодо удосконалення деяких положень» від 05.10.2017 р. № 2164-VIII [1] на законодавчому рівні ухвалено базу для запровадження консолідованого звіту про управління в національну практику звітування, який призначений як інформаційне забезпечення прийняття управлінських рішень менеджментом групи підприємств на якісно новому рівні. У зв'язку з цим набуває актуальності питання визначення змісту консолідованого звіту про управління.

Аналіз останніх досліджень та публікацій. Питанням звіту про управління присвячені праці як вітчизняних, так і зарубіжних авторів. Т. Бондар розглядає етапи складання звіту про управління [2]. О. Гандзюк надає характеристику розділів звіту про управління та їх змістовне інформаційне наповнення для будівельних підприємств [3]. I. Жураковська [4] та А. Озеран [5] розглядають звіт про управління як елемент фінансової звітності, а Л. Ловінська [6] наводить зміст, мету, склад, сферу застосування звіту про управління. О. Малишкін [7] розглядає зміст і призначення звіту про управління. Л. Стецюк [8] наголошує, що із запровадженням звіту про управління підготовка звітності виходитиме за межі бухгалтерських служб. Н. Бейн [9] наводить склад звіту про управління. Не зменшуючи вагомості наукових напрацювань провідних авторів, зауважимо, що питання концептуальних основ консолідованого звіту про управління не знайшли достатнього опрацювання в їх дослідженнях.

Метою дослідження є аналіз законодавчих новацій стосовно консолідованого звіту про управління в українській практиці звітування.

Виклад основного матеріалу. Консолідований звіт про управління - документ (комплект документів), що містить фінансову та нефінансову інформацію, яка характеризує стан і перспективи розвитку групи підприємств та розкриває основні ризики і невизначеності їі діяльності.

(C) К. В. Безверхий, В. П. Пантелеєв, 2018 
Консолідований звіт про управління подається разом із консолідованою фінансовою звітністю в порядку та строки, встановлені законом. У разі подання підприємством консолідованої фінансової звітності подається консолідований звіт про управління.

Консолідований звіт про управління є важливим елементом фінансової звітності групи підприємств. У ньому необхідно надавати справедливий огляд розвитку групи підприємств та їх стану, який відповідав би розміру і складності бізнесу. Ця інформація повинна не лише обмежуватися фінансовими аспектами діяльності групи підприємств, а й включати аналіз екологічних та соціальних аспектів діяльності групи підприємств, необхідних для розуміння користувачами звітності розвитку, результатів діяльності або стану групи підприємств. Якщо консолідований звіт про управління та звіт про управління материнської компанії представлені як єдиний звіт, доцільно приділити більше уваги питанням, що мають суттєве значення для підприємств, включених до узагальненого консолідованого звіту. Проте з огляду на потенційне навантаження на малі та середні підприємства країни-члени ЄС мають право не передбачати обов'язкову вимогу щодо включення нефінансової інформації у звіти про управління таких підприємств.

Консолідовані звіти про управління повинні складатися таким чином, щоб інформація про такі групи підприємств могла поширюватися між іiї членами та передаватися третім особам. Тому національне законодавство, що регулює складання консолідованих звітів про управління, повинно бути скоординоване для забезпечення принципів порівнянності та відповідності інформації, яка оприлюднюється підприємствами у межах $\mathrm{CC}[10$, п. 15]. 3 огляду на це, в Україні слід забезпечити єдині підходи до організації підготовки, складання, подання та оприлюднення консолідованого звіту про управління і викласти це в Національному положенні (стандарті) бухгалтерського обліку та розробити методичні рекомендації щодо складання вищевказаного звіту.

У таблиці наведено зміст консолідованого звіту про управління.

Табличя

\section{Зміст консолідованого звіту про управл}

Загальні вимоги. Огляд має бути збалансованим і комплексним аналізом розвитку, діяльності та стану групи підприємств, відповідно до розміру і складності бізнесу. В обсязі, необхідному для розуміння розвитку, діяльності та стану групи підприємств, аналіз включає як фінансові, так i, за необхідності, основні нефінансові показники в розрізі видів діяльності, у тому числі інформацію екологічного та соціального характеру. Огляд має бути об'єктивним, тобто містити правильну та чесну інформацію про становище, розвиток та результати діяльності підприємства, а також про основні ризики в його діяльності; чесність аудиту означає, що фінансові звіти не містять суттєвих викривлень і вірно відображають фінансові результати та становище суб'єкта господарювання.

Аналіз, що наводиться у консолідованому звіті про управління, містить сумарні показники, подані в річній фінансовій звітності, та, в разі доцільності, додаткові пояснення щодо них. Консолідований звіт про управління готує компанія, яка здійснює контроль, на основі відповідних звітів від підприємств, які вона контролює. Для потреб аналізу фінансових та основних нефінансових показників ефективності бізнесу при підготовці звіту включаються показники витрат, взяті з річної фінансової звітності, з можливими додатковими їх поясненнями. Тому підприємство, що здійснює контроль, проводить значну роботу з підготовки такого звіту про діяльність єдиної економічної одиниці. До підготовки консолідованого звіту про управління групою долучаються не лише економічний апарат управління, а й відповідні служби материнського та дочірніх підприємств.

\begin{tabular}{|l|l|}
\hline \multicolumn{1}{|c|}{ Елемент звіту } & \multicolumn{1}{c|}{ Розкриття змісту звіту } \\
\hline $\begin{array}{l}\text { Розвиток, зокрема ймо- } \\
\text { вірні перспективи по- } \\
\text { дальшого розвитку під- } \\
\text { приємства }\end{array}$ & $\begin{array}{l}\text { Прогнози розвитку підприємств групи. } \\
\text { нових сегментів ринку, нових видів товарів. }\end{array}$ \\
\hline
\end{tabular}


Мета та стратегія підприємств групи.

Структура власності підприємств групи та контролю над ними, а також структура групи підприємств, до якої входить підприємство, та відносини всередині групи.

Угоди, в яких беруть участь акціонери, частка яких у капіталі перевищує $10 \%$.

Особи, які надають групі консультаційні та інші послуги, що може призвести до конфлікту інтересів.

Посадові особи органів управління групою, розмір їх винагороди, володіння акціями товариства.

Підтвердження безперервної діяльності групи підприємств. Звіти про бізнес-середовище групи підприємств.

Звіти про проведення досліджень і розробок.

Звіти про результати фінансової та операційної діяльності. Звіти про продажі, які повинні містити не тільки дані про їх загальні обсяги, а й за видами продукції, регіонами, рентабельністю, каналами реалізації, сезонами. Це допоможе приймати кращі рішення стосовно стратегій продажів. Маркетингові плани доповнюють звіти про продажі. Маркетингові звіти допомагають визначати вплив маркетингової стратегії на продажі.

Звіти про опитування клієнтів. Фахівці з маркетингових досліджень часто проводять дослідження клієнтів телефоном, поштою та Інтернетом. Ці опитування використовуються для вимірювання рівня задоволення клієнтів продукцією

Діяльність, зокрема у сфері досліджень і розробок та послугами компанії. Власники малого бізнесу можуть також використовувати їх для визначення тих функцій продукції, які $є$ найважливішими для клієнтів. Менеджери маркетингових досліджень потім аналізують дані опитування та висвітлюють основні результати досліджень у своїх звітах. Після цього топ-менеджмент може використовувати звіт про опитування клієнтів для розроблення різних маркетингових стратегій.

Звіти про фінанси. Крім інформації про загальний бюджет та щомісячний бюджет вони містять дані, взяті з детальних бухгалтерських звітів.

Звіти про прибутки та збитки. Зазвичай складаються фінансовими менеджерами та бухгалтерами. Включають дані про місячні, квартальні та річні валові продажі, а також про витрати на замовлення продукції, рекламні акції та заробітну плату. Витрати потім вираховуються для розрахунку чистого прибутку. Звіти про прибутки та збитки використовуються для вивчення циклічності збуту. За допомогою цих звітів менеджери також встановлюють свої рекламні та інвентарні бюджети (бюджети запасів). Звіт про рух грошових коштів дає змогу побачити, коли очікуються гроші, коли потрібно сплачувати рахунки та чи достатньо грошей на рахунку, щоб сплатити їх, коли вони надійдуть. Звіти про старіння (збільшення строків погашення) дебіторської заборгованості дозволяють перевірити наявність у підприємства клієнтів або залишків, які можуть бути дефолтними. Гнучкі бюджети показують, як коригувати витрати залежно від рівня обсягу продажів. 


\begin{tabular}{|c|c|}
\hline & $\begin{array}{l}\text { Звіти про інформаційні технології. Містять дані про трафік } \\
\text { веб-сайту підприємства, які розраховуються на базі статис- } \\
\text { тики веб-сайту. Вони дозволяють визначити, які сторінки } \\
\text { веб-сайту найбільше переглядаються і ким, які ключові } \\
\text { слова сприяють підвищенню трафіку. До цих звітів також } \\
\text { включаються дані щодо кількості уподобань Fасеbоok, } \\
\text { отримуваних рекомендацій Google Plus та їх авторів; дані } \\
\text { від телефонних систем про кількість звернень; дані про } \\
\text { витрати на інформаційні технології. } \\
\text { Звіти про веб-трафік. Часто використовуються Інтернет- } \\
\text { компаніями або компаніями з веб-сайтами, містять дані про } \\
\text { перегляди веб-сторінок, унікальних відвідувачів та тих, на } \\
\text { чию думку посилаються. Використовуються для визначення } \\
\text { тривалості відвідування різних сторінок, а також часу дня, } \\
\text { на який припадає більшість трафіку. } \\
\text { Звіти про людські ресурси. Оскільки витрати на оплату праці } \\
\text { є значними на багатьох підприємствах, ці звіти використо- } \\
\text { вуються для визначення структури витрат на утримання } \\
\text { персоналу з метою їх оптимізації. } \\
\text { Звіти про соціальну діяльність та про корпоративну соціаль- } \\
\text { ну відповідальність. Основні розділи: підходи до організації } \\
\text { праці при управлінні людськими ресурсами, благодійна } \\
\text { діяльність, права людини, взаємодія із суспільством, від- } \\
\text { повідальність за продукцію. } \\
\text { Звіти про діяльність з охорони природного навколишнього } \\
\text { середовища. Основні розділи: охорона атмосфери, охоро- } \\
\text { на водних ресурсів, охорона земельних ресурсів, охорона } \\
\text { геологічного середовища, комплексна охорона довкілля, } \\
\text { застосування енергозберігаючих технологій, використання } \\
\text { природоохоронних технології тощо. }\end{array}$ \\
\hline $\begin{array}{l}\text { Інформатизація ведення } \\
\text { бухгалтерського обліку }\end{array}$ & $\begin{array}{l}\text { Сучасні інформаційні системи бухгалтерського та фінан- } \\
\text { сового обліку, управлінського обліку, обліку розрахунків } \\
\text { податків. }\end{array}$ \\
\hline $\begin{array}{l}\text { Звіт із заходів щодо якос- } \\
\text { ті продукції, надання } \\
\text { послуг }\end{array}$ & $\begin{array}{l}\text { Запровадження та реалізація заходів із підвищення та під- } \\
\text { тримання якості. }\end{array}$ \\
\hline $\begin{array}{l}\text { Стан групи підпри- } \\
\text { ємств, зокрема наяв- } \\
\text { ність філій підприємств }\end{array}$ & $\begin{array}{l}\text { Перелік дочірніх підприємств, що входять до складу групи } \\
\text { підприємств, основні відомості про діяльність дочірніх } \\
\text { підприємств. } \\
\text { Перелік філій, відокремлених підрозділів, підприємств, що } \\
\text { утворюють сегменти діяльності. }\end{array}$ \\
\hline $\begin{array}{l}\text { Основні ризики і } \\
\text { невизначеності, } 3 \text { якими } \\
\text { стикається група } \\
\text { підприємства }\end{array}$ & $\begin{array}{l}\text { Істотні фактори ризику, що впливають на діяльність групи } \\
\text { підприємств, мета, об'єкти, суб’єкти, елементи механізму } \\
\text { управління ризиками, хеджування, страхування. } \\
\text { Операційні ризики, фінансові ризики, ринкові ризики, ва- } \\
\text { лютні ризики, кредитні ризики, ризики зміни відсоткових } \\
\text { ставок, ризики ліквідності, ризик втрати контролю інші } \\
\text { ризики групи. } \\
\text { Постійна оцінка змінюваності умов, трансформація, швидка } \\
\text { та гнучка переорієнтація виробництва, дії конкурентів, зміна } \\
\text { кон'юнктури ринку тощо. }\end{array}$ \\
\hline
\end{tabular}

Джерело: складено на основі [10; 11; 12] 
Відповідно до ст. 29а Директиви 2013/34/ЄС, підприємства, що мають суспільне значення і $є$ материнськими компаніями великої групи, в яких на дату складання балансу на консолідованій основі значення такого критерію, як середня кількість працюючих протягом фінансового року, досягає 500 осіб, повинні включити у консолідований звіт про управління консолідовану нефінансову інформацію. Ця інформація повинна надавати необхідне уявлення про стан діяльності та розвиток такої групи, а також вплив іiі діяльності на такі аспекти: екологічний, соціальний, зайнятість, права людини, боротьба 3 корупцією та хабарництвом. Нефінансова інформація подається за такою схемою:

a) короткий опис бізнес-моделі групи;

b) опис політики групи щодо вищевказаних аспектів, включаючи впровадження процесу дью-ділідженс (англ. due diligence - належна добросовісність);

c) досягнуті результати політики;

d) істотні ризики, пов’язані із зазначеними аспектами, які виникають у зв'язку 3 діяльністю групи і залежать від групи, включаючи комерційні відносини з іншими контрагентами, продукцію та послуги, які з високою ймовірністю можуть спричинити значні несприятливі наслідки у вищевказаних аспектах, а також інформацію про заходи, вжиті групою для управління цими ризиками;

е) ключові нефінансові показники, які стосуються відповідних аспектів.

У разі, якщо група не проводить політику стосовно одного або більше із вищевказаних аспектів, у консолідованому нефінансовому звіті повинна вказуватися чітка $і$ аргументована причина їі відсутності [11]

Згідно з п. 11.7 ст. 11 Закону України “Про бухгалтерський облік та фінансову звітність в Україні” [12], у разі подання підприємством консолідованої фінансової звітності подається консолідований звіт про управління. Від подання звіту про управління звільняються мікропідприємства та малі підприємства. Середні підприємства мають право не відображати у консолідованому звіті про управління нефінансову інформацію. Також відповідно до п. 23.1 ст. 23 Директиви 2013/34/СС [11] малі групи звільняються від обов'язкового складання консолідованої фінансової звітності та консолідованого звіту про управління, крім випадку, коли будь-яке з афілійованих підприємств є суспільно значимим суб'єктом господарювання. Вищевказані положення відображають імплементацію вимог Директиви 2013/34/СС [11] та Директиви 2014/95/СС [10] в українську практику подання консолідованого звіту про управління.

У 2018 році обрані компанії країн ЄС вже мають представити нефінансові показники у консолідованому звіті про управління. Обрані компанії - це компанії, які мають понад 500 співробітників або акції яких котуються на біржі, або страхові компанії та банки. Сврокомісія підрахувала, що Директива 2013/34/СС [11] торкнеться 6000 компаній, а вартість підготовки такого звіту коштуватиме 5000 євро. Для полегшення звітування Сврокомісія підготувала добровільне керівництво зі звітування, що має допомогти компаніям визначити основні принципи і питання консолідованої фінансової звітності. До грудня 2016 року країни мали закінчити транспонування Директив 2013/34/ЄС та 2014/95/ЄС у національні законодавства, але це зробили не всі члени ЄС. Втім у деяких країнах, наприклад в Італії, запропоновано дуже суттєві штрафи (від 25000 до 100000 євро) для керівництва компаній, а також аудиторів [2, с. 115].

В Україні поки що не затверджено єдиний нормативний документ, який регламентує порядок складання звіту про управління (далі - Звіт). Процес підготовки Звіту розкрито у Керівництві зі звітності країн щодо цілей сталого розвитку (Guidelines to Support Country Reporting on the Sustainable Development Goals), розробленому в рамках Глобальної ініціативи зі звітності (Global Reporting Initiative) [13]. Він складається 3 послідовності таких дій:

1) визначення обсягу консолідації даних; визначення груп зацікавлених сторін для відображення в Звіті;

2) розроблення формату та структури Звіту, а також порядку розрахунку окремих показників результативності діяльності;

3) збирання даних і складання звіту про стійкий розвиток;

4) перевірка якості Звіту шляхом проведення внутрішнього аудиту, опитувань зацікавлених сторін та/або незалежної зовнішньої аудиторської перевірки, виправлення виявлених недоліків; 
5) публікація Звіту та забезпечення його доступності для зацікавлених сторін [2, с. 115].

Як зазначає Т. Бондар, складання Звіту здійснювати у п’ять етапів:

I. Підготовчий етап, включає визначення: мови звіту, ресурси та часовий період, рівень верифікації; обсягу консолідації даних; груп зацікавлених сторін; тем, що становлять найбільший інтерес; установ і організацій, для яких окреслені теми є найактуальнішими; проведення серії зустрічей (індивідуальних, конференцій, семінарів, громадських слухань, інтерактивних Інтернет-форумів та/або опитувань, консультацій і круглих столів) із представниками державної та місцевої влади, комерційними партнерами, споживачами й іншими зацікавленими сторонами для вивчення їх позиції та очікувань; вибір конкретних експертів для запрошення до діалогу; створення робочої групи з різних відділів для підготовки Звіту (до складу групи залучають представників різних відділів).

II. Збирання та перевірка інформації, включає: процес збирання даних, який повинен бути зафіксований на підприємстві окремою процедурою; формування базової сукупності ключових показників; визначення джерел інформації (які включають інформацію звітів компанії, фінансову та бухгалтерську інформацію, дані звітів із закупівель, дані екологічних оглядів та оцінки екологічного та соціального впливу компанії, інформацію звітів щодо кількості, якості й відгуків стосовно проведених тренінгів, оцінку рівня задоволеності співробітників тощо); систематизацію та структурування даних; аналіз і перевірку даних.

III. Написання та оформлення Звіту здійснюється відповідальним за його складання, яким може бути як працівник підприємства, так і зовнішній експерт; складається текстова частина Звіту, а також ілюстративна (графіки, таблиці, коментарі), яка розширює його комунікативні цілі.

IV. Aудит і верифікація Звіту включає проведення внутрішнього аудиту, опитувань зацікавлених сторін i/або незалежної зовнішньої аудиторської перевірки, виправлення виявлених недоліків; разом із тим країни-члени ЄС можуть вимагати проведення додаткової перевірки інформації незалежним експертом, який надає висновки щодо такого роду інформації.

V. Публікаиія Звіту та забезпечення його доступності для заиікавлених сторін забезпечується його розміщенням окремою сторінкою на сайті компанії (або сайті для iї нефінансового звіту); розміщенням адреси та контактів для надсилання коментарів із зазначенням контактної особи з питань підготовки Звіту; розповсюдженням Звіту серед зацікавлених сторін (організація круглих столів, прес-конференцій, розсилка прес-релізів як співробітникам, так і засобам масової інформації та іншим зовнішнім зацікавленим сторонам, повідомлення для інвесторів, реклама, електронні листи й інші форми комунікації); здійснення оцінки залученої кількості зацікавлених сторін, ефективності каналів комунікації і кількості наданих коментарів, які можна включити в управління соціальною відповідальністю і у наступний цикл звітування.

При складанні Звіту суттєвого значення набуває взаємодія підрозділів групи підприємств у процесі діяльності, яка забезпечує поліпшення репутації та іміджу компанії/ підприємства, підвищення стійкості шляхом зниження ризиків, зростання ефективності окремих бізнес-процесів, у поліпшенні інвестиційної привабливості шляхом підвищення довіри до компанії і підвищення ііі капіталізації, утримання кваліфікованих кадрів. Складання Звіту забезпечить ефективність стратегічного й тактичного менеджменту підприємства, координацію і комунікацію усіх його підрозділів [2, с. 116].

Висновки і перспективи подальших досліджень. Консолідований звіт про управління $\epsilon$ новим явищем у практиці звітування в Україні, що обумовлено прийняттям змін до Закону України "Про бухгалтерський облік та фінансову звітність в Україні" [1]. Це забезпечить імплементацію норм європейського законодавства в українську практику звітування суб' єктами господарювання. Консолідований звіт про управління призначений для виведення інформаційного забезпечення суб'єктів господарювання на якісно новий рівень. В подальших наукових дослідженнях вбачається за доцільне провести дискусію щодо розроблення типових форм консолідованого звіту про управління, Національного стандарту (положення) бухгалтерського обліку “ЗВііт про управління” та методичних рекомендації щодо складання консолідованого звіту про управління (алгоритмів його заповнення). 


\section{Список використаних джерел}

1. Закон України “Про внесення змін до Закону України «Про бухгалтерський облік та фінансову звітність в Україні» щодо удосконалення деяких положень” від 05.10.2017 p. № 2164-VIII [Електронний ресурс]. URL: http://zakon0.rada.gov.ua/ laws/show/2164-19.

2. Бондар Т. А. Звіт про управління: етапи складання // Сучасні тенденції розвитку обліку, оподаткування, аналізу і аудиту: зб. матеріалів міжнар. наук. інтернет-конф., 17 листопада 2017 р., м. Київ. К.: КНЕУ, 2017. С. $115-117$.

3. Гандзюк О. В. Формування облікової звітності як складової інформаційної системи підприємства: дис. ... канд. екон. наук: 08.00.09 “Бухгалтерський облік, аналіз та аудит". Тернопіль, 2017. 277 с.

4. Жураковська I. В. Майбутні події як об'єкт управлінського та фінансового обліку // Розвиток обліку, аналізу і аудиту суб' єктів суспільного інтересу: тези вист. міжнар. наук. конф., 20-21 жовтня 2017 р., м. Житомир. Житомир: Видавець О. О. Свенок, 2017. C. $52-54$.

5. Озеран А. В. Гармонізація фінансової звітності підприємств 3 міжнародними стандартами та потребами управління: дис. ... докт. екон. наук: 08.00.09 “Бухгалтерський облік, аналіз та аудит”. К., 2015. 570 с.

6. Ловінська Л. Г. Вплив євроінтеграційних процесів на розвиток бухгалтерського обліку та звітності в Україні // Фінанси України. 2014. № 9. С. 21 -30.

7. Малишкін О. I. Призначення і зміст звіту про управління // Фінансова система України в умовах економічної та фінансової глобалізації світу: зб. матер. всеукр. наук.-практ. конф. Том 1. Київ, 15 грудня 2017 року / За ред. проф. В. М. Фурмана. Київський інститут банківської справи, 2017. С. 215-219.

8. Стецюк Л. С. Нефінансова звітність як інструмент для забезпечення прозорості бізнесу // Розвиток бухгалтерського обліку, фінансів та оподаткування в аграрному секторі економіки в умовах євроінтеграції: матер. X міжнар. наук.-практ. конф. (24 листопада 2017 р., м. Київ) / Відп. за вип. Ю. С. Бездушна. К.: ННЦ “ІАЕ”, 2017. C. 155-157.

9. Bain N., Band D. Winning Ways through Corporate Governance. Palgrave Macmillan UK, 1996. $211 \mathrm{p}$.

10. Directive2014/95/EU of the European Parliament and of the Council of 22 October 2014 amending Directive2013/34/EU as regards disclosure of non-financial and diversity information by certain large undertakings and groups [Electronic resource]. URL: http:// eur-lex.europa.eu/legal-content/EN/TXT/HTML/?uri=OJ:L:2014:330:FULL\&from=E N\#L 2014330 EN.01000101.doc.

11. Directive 2013/34/EU of the European parliament and the council of 26 June 2013 on the annual financial statements, consolidated financial statements and related reports of certain types of undertakings, amending Directive 2006/43/EC of the European Parliament and of the Council and repealing Council Directives 78/660/EEC and 83/349/EEC [Electronic resource]. URL: http://www.oroc.pt/fotos/editor2/diretivacont.pdf.

12. Закон України "Про бухгалтерський облік та фінансову звітність в Україні" від 16.07.99 p. № 996 - XI [Електронний ресурc]. URL: http://zakon4.rada.gov.ua/laws/ show/996-14.

13. Global Reporting Initiative [Electronic resource]. URL: https://www.globalreporting. org/Pages/default.aspx.

14. Закон за счетоводството [Електронний ресурс]. URL: https://zakonnik.bg/document/ view/other/149848/5273327.

\section{References}

1. Zakon Ukrainy "Pro vnesennia zmin do Zakonu Ukrainy 'Pro bukhhalterskyi oblik ta finansovu zvitnist v Ukraini' shchodo udoskonalennia deiakykh polozhen" [The Law of Ukraine "Amendments to the Law of Ukraine "Accounting and financial reporting in Ukraine”, for the improvement of some provisions] from 05.10.2017 r. № 2164-VIII. URL: http://zakon0.rada.gov.ua/laws/show/2164-19 [in Ukrainian].

2. Bondar T. A. (2017). Zvit pro upravlinnia: etapy skladannia [The report about management: phases of compilation]. Suchasni tendentsii rozvytku obliku, opodatkuvannia, 
analizu i audytu: zb. materialiv mizhnar. nauk. internet-konf. - Current tendencies in accounting, taxation and audit: proceedings of intern. Scientific and practical conf. K.: KNEU, P. 115-117 [in Ukrainian].

3. Handziuk O. V. (2017). Formuvannia oblikovoi zvitnosti yak skladovoi informatsiinoi systemy pidpryiemstva: dys. ... kand. ekon. nauk: 08.00.09 "Bukhhalterskyi oblik, analiz ta audyt" [Forming the accounting records: a component in the information system of an enterprise: thesis for PhD (Economics)]. Ternopil [in Ukrainian].

4. Zhurakovska I. V. (2017). Maibutni podii yak obiekt upravlinskoho ta finansovoho obliku [Future events: an object of management and financial accounting]. Rozvytok obliku, analizu i audytu subiektiv suspilnoho interesu: tezy vyst. mizhnar. nauk. konf. - The development of accounting, analysis and audit of the subjects of social interest: abstracts of intern. scientific conf. Zhytomyr: Publisher O. O. Yevenok. P. 52-54 [in Ukrainian].

5. Ozeran A. V. (2015). Harmonizatsiia finansovoi zvitnosti pidpryiemstv z mizhnarodnymy standartamy ta potrebamy upravlinnia: dys. ... dokt. ekon. nauk: 08.00.09 "Bukhhalterskyi oblik, analiz ta audyt" [Harmonization of financial reporting of enterprises with international standards and management needs; doctoral thesis (Economics)]. Kyiv, 2015 [in Ukrainian].

6. Lovinska L. H. (2014). Vplyv yevrointehratsiinykh protsesiv na rozvytok bukhhalterskoho obliku ta zvitnosti v Ukraini [The impact of Eurointegration processes on the development accounting and reporting in Ukraine]. Finansy Ukrainy - Finance of Ukraine, 9, 21-30 [in Ukrainian].

7. Malyshkin O. I. (2017). Pryznachennia i zmist zvitu pro upravlinnia [The purpose and contents of the report on management]. Finansova systema Ukrainy v umovakh ekonomichnoi ta finansovoi hlobalizatsii svitu: zb. mater. vseukr. nauk.-prakt. konf. The financial system in Ukraine in the context of economic and financial globalization: proceedings of All-Ukrainian scientific and practical conf. Kyiv Institute of Banking, P. 215-219 [in Ukrainian].

8. Stetsiuk L. S. (2017). Nefinansova zvitnist yak instrument dlia zabezpechennia prozorosti biznesu [Non-financial reporting: an instrument ensuring the transparence of business]. Rozvytok bukhhalterskoho obliku, finansiv ta opodatkuvannia $v$ ahrarnomu sektori ekonomiky v umovakh yevrointehratsii: mater. 10 mizhnar. nauk.-prakt. konf. - The development of accounting, finance and taxation in the agrarian sector of the economy in the Eurointegration context: proceedings of the 10th intern. scientific and practical conf. Kyiv: NNTs "IAE", P. 155-157 [in Ukrainian].

9. Bain N., Band D. (1996). Winning Ways through Corporate Governance. Palgrave Macmillan UK.

10. Directive2014/95/EU of the European Parliament and of the Council of 22 October 2014 amending Directive2013/34/EU as regards disclosure of non-financial and diversity information by certain large undertakings and groups. URL: http://eur-lex.europa.eu/ legal-content/EN/TXT/HTML/?uri=OJ:L:2014:330:FULL\& from=EN\#L_2014330 EN.01000101.doc.

11. Directive 2013/34/EU of the European parliament and the council of 26 June 2013 on the annual financial statements, consolidated financial statements and related reports of certain types of undertakings, amending Directive 2006/43/EC of the European Parliament and of the Council and repealing Council Directives 78/660/EEC and 83/349/EEC. URL: http://www.oroc.pt/fotos/editor2/diretivacont.pdf.

12. Zakon Ukrainy "Pro bukhhalterskyi oblik ta finansovu zvitnist v Ukraini" [Law of Ukraine "Accounting and financial reporting in Ukraine] from 16.07.99 No 996 - XI. URL: http://zakon4.rada.gov.ua/laws/show/996-14 [in Ukrainian].

13. Global Reporting Initiative. URL: https://www.globalreporting.org/Pages/default.aspx.

14. Zakon za schetovodstnoto [Law on accounting]. URL: https://zakonnik.bg/document/ view/other/149848/5273327 [in Bulgarian]. 
К. В. БЕЗВЕРХИЙ,

кандидат экономических наук, докторант кафедры учета и налогообложения,

ГВУЗ «Киевский национальный экономический университет имени Вадима Гетьмана»;

В. П. ПАНТЕЛЕЕВ

доктор экономических наук, профессор, профессор кафедры учета и налогообложения, Национальная академия статистики, учета и аудита

\section{Консолидированный отчет об управлении. Новации управленческой практики отчетности}

Консолидированный отчет об управлении является новым явлением в практике отчетности в Украине, что обусловлено принятием изменений в Закон Украины «О бухгалтерском учете и финансовой отчетности в Украине». Консолидированный отчет об управлении предназначен для выведения информачионного обеспечения группь предприятий на качественно новый уровень. Результаты проведенного исследования обеспечивают базу для гармонизации отчетности в Украине со стандартами ЕС. Они рекомендуются для использования на всех группах предприятий Украины в разных секторах экономики, которые должны будут составлять консолидированный отчет об управлении.

Ключевые слова: консолидированная финансовая отчетность, консолидированный отчет об управлении, группа предприятий, нефинансовая информация, показатель.

K. V. BEZVERKHIY,

PhD (Economics), Doctoral Student, Department of Accounting and Taxation,

Kyiv National Economic University named after Vadym Hetman;

V. P. PANTELEEV,

doctor of economic sciences, professor,

Professor of Accounting and Taxation Department, National Academy of Statistics, Accounting and Auditing

\section{Consolidated Management Report. Innovations in Managerial Reporting Practices}

Consolidated report on management is a new phenomenon in the Ukrainian reporting practices due to the adoption of amendments to the Law of Ukraine "On Accounting and Financial Reporting in Ukraine". The consolidated management report is intended to bring the information provision of a group of companies up to a radically new level. An extensive review of the content of the consolidated management report is made, to show that it represents an important component in the financial reporting of a group of companies; it should contain true and fair overview of the performance of a group of companies, conforming to the scopes and complexity of their business; this information should not be confined to financial aspects of business, but should encompass analysis of ecological and social issues of the business, which users of the reporting need to comprehend business performance, trends and prospects of the company group. A comparative review of legal acts of EU and Ukraine on consolidated report is given. The procedure for presenting non-financial information in the report by the EU practice is highlighted. The specifics of consolidated financial reporting for micro-, small and medium companies are shown. Results of the study can contribute to solutions of problems related with harmonization of reporting in Ukraine with the EU standards. There are recommended for use at all the groups of companies in Ukraine, in various economic sectors, which are expected to make consolidated management repor. 
Keywords: consolidated financial reporting, consolidated management report, group of companies, non-financial information, indicator.

\section{Посилання на статтю:}

Безверхий К. В., Пантелеєв В. П. Консолідований звіт про управління. Новації управлінської практики звітування //Науковий вісник Національної академії статистики, обліку та аудиту: зб. наук. пр. 2018. №1-2. С. 37-46. 